\title{
The Effectiveness of POE (Predict-Observe-Explain) Learning Model for Improving Student Analytical Skills
}

\author{
Siti Sarah ${ }^{1}$, Ahmad Khanif ${ }^{2}$, Ade Tegar Saputra ${ }^{3}$ \\ Universitas Sains Al Qur'an, Indonesia ${ }^{1,2}$, SMA Bhakti Tunas Harapan, Indonesia ${ }^{3}$ \\ st.sarah44@gmail.com ${ }^{1}$, ahmadkhanif908@gmail.com ${ }^{2}$, tegaradhe@gmail.com
}

Received: July $16^{\text {th }}, 2020$. Revised: September $3^{\text {rd }}, 2020$. Accepted: September $8^{\text {th }}, 2020$

Keywords :

POE Learning Model;

Analytical Skills; Effectiveness

\begin{abstract}
This study aims to determine (1) differences in students' analytical skills in learning physics with the POE (PredictObserve-Explain) learning model and direct instruction learning, (2) improve students' analytical skills by learning physics POE learning models. This study uses a quasiexperimental method and control-group pre-test post-test design. The research subjects were Grade VIII students of a junior high school in a District of Wonosobo Regency, Central Java. The data instruments is test. Data analysis techniques using different test and gain test. The results showed: (1) there were differences in analysis skills between students who used the POE learning model and did not use the POE model seen from the results of the $t$-test with $d k 47$ and 5\% significance level where tcount $>$ ttable was 5.49> 2.012, (2) improvement of students' analytical skills using the POE model is greater than the students who do not use the POE model with a gain test of 0.60 (medium criteria)> 0.32 (medium criteria).
\end{abstract}

\section{INTRODUCTION}

The 2013 curriculum is a curriculum that applies to Indonesia, starting from elementary to secondary level. Since its implementation until now, the 2013 Curriculum has been amended several times, now it is known as the revised edition of the 2013 Curriculum. The new thing contained in the curriculum is learning that applies the concept of HOTS (Higher Order Thinking Skill).

HOTS or higher-order thinking ability is a process of thinking of students at a higher cognitive level. HOTS was developed from various concepts, cognitive methods, and learning taxonomies [1]. HOTS includes aspects of critical thinking skills, creative thinking, and problem-solving. Critical thinking is the ability to analyze, create, use criteria objectively, and evaluate data [2]. Other experts, namely Marshall \& Horton [3] and Bagarukayo et al [4] stated HOTS included: making decisions, solving problems, thinking critically, analyzing, synthesizing, and interpreting. HOTS measures the ability to: 1) transfer one concept to another, 2) process and apply information, 3) look for relationships of different kinds of information, 4) use information to solve problems and 5) critically examine ideas and information [5]. The Australian Council for Educational Research [6] states that the ability to think at a higher level is a thought process, including analyzing, reflecting, giving arguments, applying concepts 
to different situations, composing, and creating. So it can be concluded that HOTS includes the ability to think critically, think creatively, and solve problems. Critical thinking as part of HOTS can be achieved through several processes, one of which is the ability to analyze. Analysis skills are useful in aspects of students' knowledge and understanding [7]. The low analytical skills make students unable to think critically optimally. As a result, not achieving HOTS. The application of the HOTS approach can improve student learning outcome [8].

Physics is the basis of science that studies the behavior and structure of matter. Creative activity is an element of physics learning. A critical aspect of physics is the observation of natural phenomena, including planning and conducting experiments [9]. The Republic of Indonesia's Minister of Education and Culture Regulation No. 24 the Year 2016 concerning core competencies and essential high school physics competencies based on 2013 Curriculum mentions four competency points for students after studying physics. One of them is to formulate problems related to physical phenomena, formulate hypotheses, design and carry out experiments, take careful measurements, record or present results in tables and graphs, make conclusions, and report results verbally or in writing. Physics learning is loaded with scientific processes carried out creatively. The right way to teach physics is to pay attention to the characteristics of learning physics.

The success of physics learning in schools does not only depend on the formulation of the curriculum but is influenced by the availability of adequate learning facilities such as laboratories [10]. Other experts recommend 27 ways for successful physics teachers to teach physics. Some of them are present concrete examples, trying to find things that seem analogous to the relationship between abstract and real facts in nature, use demonstrations and laboratory activities to shape the imagination and crystallization of knowledge, careful and honest behavior in conducting observational activities in the laboratory [11]. The study results explained that the way to teach physics well is through a scientific process so that the competencies of students after carrying out physics learning are met. One indicator of student competence is reflected in the physics test scores.

The final assessment data for grade VIII students at a junior high school in Wonosobo Regency, Central Java showed that $68 \%$ of students did not meet the minimum completeness criteria. The minimum completeness criterion value of physics lessons in junior high is 76 . These results indicate that the mastery of students in physics subjects is not satisfactory. Even though the junior high school has implemented a revised edition 2013 curriculum. The results of observations on physics learning class VIII at a junior high school in Wonosobo Regency, Central Java showed that students tend to be less active in learning during the learning process. In general, students only hear the teacher's explanation without actively seeking additional knowledge about the material being studied. These findings indicate that learning physics in a junior high school in Wonosobo Regency, Central Java has not met the curriculum's demands.

POE (Predict-Observe-Explain) is one of the learning models that can involve students to be active in learning. POE consists of 3 stages, namely predict, observe, and explain. Predict is the students make predictions of the problem solution and predict the results that will be done in the next step. (2) Observe, namely, students observing experiments. (3) Explain students compare the results of observations in observations with predictions and then explain their knowledge [12]. Learning using the POE model can increase learning activities [13], analytical skills [14], and students' critical thinking skills [15]. Increasing students' critical thinking skills affects increasing HOTS, an indicator of learning achievement [16].

Based on the problems in physics learning for grade VIII students of at a junior high school in Wonosobo Regency, Central Java and the many references that support the POE model, this paper aims to find out whether there are differences in the ability to analyze students who use POE and who do not use the POE model. Another goal is to determine the increase in the ability to analyze students learning physics using the POE mode. This paper can be a reference in implementing physics learning that can develop the ability to analyze to achieve HOTS, where learning achievement is one of the indicators. This 
research will also show how the POE model can improve the analytical skills of students with low academic abilities. The academic ability of students of junior high school in Wonosobo Regency is generally low.

\section{METHOD}

The research method is quasi-experimental with a control-group pre-test post-test design. The research subjects were grade VIII students of a junior high school in Wonosobo Regency, Central Java, which consisted of two classes: the experimental and control classes. The experimental class contains students who conduct learning using POE. The control class consists of students doing learning using the direct instruction method. Determination of the control class and the experimental class based on the results of the two classes' average similarity test. Data collection instruments in the form of tests to determine students' analytical skills in solving physics problems. The test takes the form of a description of 12 items that have been proven to meet the tests of validity, reliability, difference power, and level of difficulty data analysis techniques using different test and gain test. The different test aims to determine whether there are differences in the ability to analyze between students who use the POE model and who use direct instruction. Before a different test is performed, an analysis prerequisite test will be conducted, namely the normality test and the homogeneity test. The gain test is used to determine the increase in students' ability to analyze after using the POE model and direct instruction using the following equation.

$$
<g>=\frac{<S_{f}>-<S_{i}>}{100-<S_{i}>}
$$

Information:

$\langle\mathrm{g}\rangle \quad=$ normalized gain score

$\left\langle\mathrm{S}_{\mathrm{f}}\right\rangle=$ average final score (postest)

$\left\langle\mathrm{S}_{\mathrm{i}}\right\rangle=$ average initial score (pretest)

The interpretation of the normalized gain calculation results uses the classification in Table 1 [17].

Table 1. Classification of Normalized Gain Score

\begin{tabular}{cc}
\hline Gain Score & Interpretation \\
\hline$<\mathrm{g}>\geq 0,7$ & High \\
$0,7><\mathrm{g}>\geq 0,3$ & Mid \\
$\langle\mathrm{g}\rangle<0,3$ & Low \\
\hline
\end{tabular}

\section{RESULTS AND DISCUSSIONS}

\section{Initial Ability Test Similarity}

The average score similarity test was conducted to find out whether the two classes to be selected as the control class and the experimental class had the same situation. The average similarity test results for the two classes can be seen in Table 2. Based on Table 2 it is known that tcount $<$ ttable $(-0.44<2.012)$. If the $t$ value is greater than the $t$ table value, it means that there is a significant difference [18]. Thus, both classes meet the requirements to be used as the experimental class and the control class.

Table 2. Average Similarity Test Results

\begin{tabular}{ccc}
\hline $\mathbf{d k}(\mathbf{5 \%})$ & $\mathbf{t}_{\text {count }}$ & $\mathbf{t}_{\text {table }}$ \\
\hline $26+23-2=47$ & $-0,44$ & 2,012 \\
\hline
\end{tabular}

The next step is implementing learning using the POE model in the experimental class and learning using the direct instruction method in the control class to get data in the form of the ability to analyze 
the questions. Before the data were analyzed using different tests, an analysis prerequisite test was carried out.

\section{Test analysis prerequisites}

Analysis prerequisite tests include homogeneity tests and normality tests. A homogeneity test is used to test whether the sample comes from a homogeneous population or not. Homogeneity test results with a significance level of 5\%, and 47 degrees of freedom are listed in Table 3. Based on Table 3, it is known that $\mathrm{F}_{\text {count }}<\mathrm{F}_{\text {table }}(1.222<2.019)$. If $\mathrm{F}$ is smaller than the $\mathrm{F}$ table, then the data will have a homogeneous distribution [19]. That is, data come from homogeneous populations.

Table 3. Homogeneity Test Results

\begin{tabular}{ccc}
\hline $\mathbf{d k}(\mathbf{n}-\mathbf{2}) \mathbf{( 5 \% )}$ & $\mathbf{F}_{\text {count }}$ & $\mathbf{F}_{\text {table }}$ \\
\hline $26+23-2=47$ & 1,22593 & 2,01964 \\
\hline
\end{tabular}

Normality test that aims to determine whether the research subjects come from a normal population. The results of the normality test are in Table 4 . Table 4 shows that the calculated $X^{2}$ value is smaller than the $X^{2}$ table in the experimental class and control class with a significance of $5 \%$. The data is said to meet the normal distribution if the $\chi^{2}$ value is smaller than the $\chi^{2}$ table [19]. Thus, the research data in the experimental class and control class fulfilled the normal distribution.

Table 4. Normality Test Results

\begin{tabular}{ccc}
\hline & Experiment Class & Control Class \\
\hline $\mathrm{N}$ & 26 & 23 \\
significance & $5 \%$ & $5 \%$ \\
$\chi_{\text {count }}^{2}$ & 3,93 & 3,12 \\
$\chi_{\text {table }}^{2}$ & 11,07 & 11,07 \\
\hline
\end{tabular}

\section{Different Test}

When the normality test and homogeneity test are met, it shows that the research data meet the elements using parametric statistics. The different test used was a t-test to determine differences in analytical skills between students who learned to use POE and who used direct instruction. Based on Table 5, it can be seen that $t_{\text {count }}>t_{\text {table }}(5.49>2.012)$ at a significance level of $5 \%$. If the $t$ value is greater than the $\mathrm{t}_{\text {table }}$ value, it means that there is a significant difference [18]. There are differences in the ability to analyze learners who learn to use the POE learning model and who use the direct instruction method.

Table 5. t-test Results

\begin{tabular}{ccc}
\hline $\mathbf{d k} \mathbf{( 5 \% )}$ & $\mathbf{t}_{\text {count }}$ & $\mathbf{t}_{\text {table }}$ \\
\hline $26+23-2=47$ & 5,49 & 2,012 \\
\hline
\end{tabular}

The results of the t-test were then continued with the gain test to find out the improvement in students' analyzing skills using Equation 1 and reference criteria in Table 1. The results of the gain test in the experimental class and the counter class can be seen in Table 6 . Based on Table 6 , it is known that the ability to analyze students is improved. Those who use the POE model are higher at 0.60 (medium criteria) than students who study without using the POE model that is 0.32 (medium criteria). Thus, the POE model is significantly proven effective in increasing the ability to analyze compared to the direct instruction learning model.

Table 6. Experimental Class and Control Class Gain Test Results

\begin{tabular}{ccc}
\hline Average & Experiment Class & Control Class \\
\hline Pre-test & 49,58 & 51,04 \\
Post-test & 79,81 & 66,87 \\
Gain & 0,60 & 0,32 \\
Criteria & Mid & Mid \\
\hline
\end{tabular}


POE learning model is a learning model that has 3 phases, namely Predict, Observe, and Explain. The POE learning model has advantages, among others: it can be used to uncover students 'initial ideas, generate discussion, provide information to teachers about students' thoughts, motivate students to wish to explore concepts, and arouse the desire to investigate. The POE model exposes students' knowledge, allows students to interpret their new observations about the world around them, and then offers more opportunities to share and negotiate their interpretations [20]. This can be seen clearly from the physics learning carried out by students using the POE model. Through the POE model, students' curiosity arises. As a result, students become more active in learning physics. Based on this it can be concluded that the POE learning model can foster analytical skills.

This is evidenced through research that shows that there are significant differences in the ability of analysis in students who use the POE learning model and without using the POE model in physics learning in a junior high school in Wonosobo Regency, Central Java. The POE model is conclusively proven to improve the ability to analyze with an increase of 0.60 with moderate criteria. Achievement of analytical skills in students who use POE models is better than students who do not use POE models that only reach an increase of 0.32 with moderate criteria. Besides, it can be seen in the gain value; the achievement of students' analytical skills using the POE learning model can also be seen from the average posttest score of 79.81. The value is higher than the average posttest value of students who use the direct instruction method, which is 66.87. For more details, see Table 6. Previous studies support the results of the study [14]. Other research also shows that the POE learning model is better in achieving science learning outcomes [21] [22]. The application of POE will be more accessible if previously prepared worksheets lead to the use of learning POE models so that learning can run effectively as a result of research [23].

Improving the ability to analyze by students after learning physics using the POE model is expected to improve critical thinking skills [15], creative thinking skills [24] and problem solving skills [25]. If students have owned all of these abilities as a result of learning to use POE, then students' learning achievement will increase. This has been proven by previous research [26] [27] [28] [29].

The results of this study imply that the use of the POE model in learning physics can improve the ability to analyze junior high school students. Although this increase is in medium criteria, it can provide an overview of the possibility of increasing HOTS through the POE model. The ability to analyze is the first step in the formation of critical thinking skills as one of the skills forming HOTS.

The school in this research is the only private junior high school in a District in Wonosobo Regency. Another junior high school in the District is public. Students of the school have lower academic abilities than students from other schools. So, the POE model can improve the analytical skills of students with low academic abilities. These results open up further research on the use of the POE model to improve the analytical skills of students with medium and high academic abilities.

\section{CONCLUSION AND SUGGESTION}

Based on data analysis, it can be concluded as follows. (1) There is a difference in the ability to analyze students using the POE learning model and the direct instructional learning model. (2) Improving the skills of analyzing students who carry out learning using the POE method (0.60) is higher than students who do not carry out POE learning (0.32).

\section{ACKNOWLEDGMENTS}

Thanks to SMP PGRI 3 KEPIL for granting a research permit. Thanks also go to several parties who have taken the time to read and review this article, so it is suitable for publication. 
The Effectiveness of POE (Predict-Observe-Explain) Learning Model for Improving Student Analytical Skills Siti Sarah, Ahmad Khanif, Ade Tegar Saputra

\section{REFERENCES}

[1] Saputra, H. (2016). Pengembangan mutu pendidikan menuju era global: Penguatan mutu pembelajaran dengan penerapan hots (high order thinking skills). Bandung: Smile's Publishing.

[2] Gunawan, A. W. (2003). Genius Learning Strategy, Petunjuk Praktis Untuk Menerapkan Accelerated Learning. Jakarta: PT. Gramedia Pustaka Utama.

[3] Marshall, J. C., \& Horton, R. M. (2011). The relationship of teacher-facilitated, inquiry-based instruction to student higher-order thinking. School Science and Mathematics, 111(3): 93-101.

[4] Bagarukayo, E., Weide, T., Mbarika, V., \& Kim, M. (2012). The impact of learning driven constructs on the perceived higher order cognitive skills improvement: Multimedia vs. text. International Journal of Education and Development using ICT, 8(2).

[5] Kemendikbud. (2017). Modul Penyusunan Soal Higher Order Thinking Skill (HOTS). Jakarta: Direktorat Pembinaan SMA Ditjen Pendidikan Dasar dan Menengah.

[6] Australian Council for Educational Research. (2015). Developing Higher Order Thinking Skill. Melbourne: ACER.

[7] Assegaff, A., \& Sontani, U. T. (2016). Upaya Meningkatkan Kemampuan Berfikir Analitis Melalui Model Problem Based Learning (PBL). Jurnal Pendidikan Manajemen Perkantoran (JPManper), 1(1): 38-48.

[8] Sofyan, F. A. (2019). Implementasi HOTS pada kurikulum 2013. INVENTA: Jurnal Pendidikan Guru Sekolah Dasar, 3(1): 1-9.

[9] Giancoli, D. C. (2011). Fisika: prinsip dan aplikasi jilid I (edisi ketujuh). (Terjemahan Irzam Hardiansyah). Erlangga: Jakarta.

[10] Azhar, A. (2011). Karakteristik fisika dan realita pendidikan nasional. Jurnal Tabularasa PPS UNIMED, 8(2): 172-182.

[11] Scheider, W. (1980). 27 commandments for physics teachers. The Physics Teacher, 18(1): 32-33.

[12] Suhaesa, A. A., Andayani, Y., Muti'ah, M., \& Anwar, Y. A. S. (2019). Pengaruh Model Pembelajaran Predict-Observe-Explain (POE) Terhadap Pemahaman Konsep Peserta didik Materi Kesetimbangan Kelarutan Kelas XI MIA SMAN 2 Labuapi Tahun Ajaran 2017/2018. Chemistry Education Practice, 1(2): 27-35.

[13] Prasetyo, R. I., Hidayat, N., \& Dimas, A. (2019, December). Studi Literature Model Pembelajaran POE (Predict, Observe, and Explain). In Prosiding SEMDIKJAR (Seminar Nasional Pendidikan dan Pembelajaran) (Vol. 3, pp. 704-710).

[14] Prasetiyaningsih, A. (2020). Meningkatkan Kemampuan Analitik Dan Aktivitas Siswa Smp Melalui Penerapan Model Pembelajaran POE (Prediction, Observation, Explanation). Jurnal Pembelajaran Fisika, 9(1): 26-34.

[15] Aida, T. N., Anggoro, S., \& Andriani, A. (2019). Analisis Berpikir Kritis Siswa Melalui Model POE (Predict-Observe-Explain) di Sekolah Dasar. Jurnal Elementaria Edukasia, 2(2): 164-172.

[16] Susanto, F., Hidayat, A., \& Maspupah, M. (2017). Penerapan Model Pembelajaran PredictObserve-Explain (Poe) Terhadap Hasil Belajar Siswa Pada Materi Sistem Indera Manusia Di Sman 3 Kota Cimahi Tahun Pelajaran 2017/2018. Jurnal Pendidikan Biologi.(1): 1-9.

[17] Hake, R. R. (1998). Interactive-engagement versus traditional methods: A six-thousand-student survey of mechanics test data for introductory physics courses. American journal of Physics, 66(1): 64-74.

[18] Budiwanto, S. (2017). Metode Statistika untuk Analisis Data Keolahragaan. Malang: Fakultas Ilmu Keolahragaan, Universitas Negeri Malang.

[19] Budiwanto, S. (2014). Metode Statistika untuk Analisis Data Bidang Keolahragaan. Malang: Universitas Negeri Malang.

[20] Warsono, \& Hariyanto. (2012). Pembelajaran Aktif. Bandung: PT. Remaja Rosdakarya. 
[21] Sumaimi, M. E. (2019). Optimalisasi hasil belajar dengan model predict-observe-explain (POE) ditinjau dari sikap empati siswa. Natural: Jurnal Ilmiah Pendidikan IPA, 6(1): 51-59.

[22] Permatasari, O. I., \& Marwoto, P. (2018). Penerapan Model Pembelajaran Predict-Observe-Explain Berbasis Kontekstual untuk Meningkatkan Aktivitas dan Pemahaman Konsep Siswa SMP. JIPF (Jurnal Ilmu Pendidikan Fisika), 2(2): 50-53.

[23] Maulida, R. A. N., Kusumawati, I., \& Wijaya, A. K. (2018). Pengembangan Buku Petunjuk Praktikum IPA Berbasis Model Pembelajaran POE (Predict Observe Explain) Pada Materi Usaha dan Energi. Jurnal Ilmu Pendidikan Fisika (JIPF), 1(3): 14-19.

[24] Sari, F. N., \& Abidin, Z. (2020). Kemampuan Berpikir Kreatif Matematis Dengan Model Pembelajaran Predict-Observe-Explain Pada Materi Kubus Dan Balok Siswa Kelas VIII SMP. Jurnal Penelitian, Pendidikan, dan Pembelajaran, 15(19).

[25] Jannah, N. L. (2017). Penerapan Model Pembelajaran POE (Predict, Observe, Explain) untuk Meningkatkan Keterampilan Pemecahan Masalah pada Mata Pelajaran IPA di Sekolah Dasar. MODELING: Jurnal Program Studi PGMI, 4(1): 132-146.

[26] Arlianty, W. N., Ashadi, A., \& Mulyani, S. (2019, June). Pembelajaran Kimia Menggunakan Model Pembelajaran Inkuiri Terbimbing Dan Predict Observe Explain (POE) Dengan Sikap Ilmiah Terhadap Prestasi Belajar Siswa Pada Materi Hidrolisis Garam. In Seminar Nasional Pendidikan 2015 (pp. 576-582).

[27] Amal, A., \& Kune, S. (2018, July). Peranan Pembelajaran Ipa Berorientasi POE (Predict, Observe, Explain) Untuk Meningkatkan Keterampilan Proses Dan Hasil Belajar Di Sekolah Dasar. In Prosiding Seminar Nasional Pendidikan (Vol. 1, No. 1).

[28] Muliartini, N. W. S., Adnyawati, N. D. M. S., \& Wahyuni, D. S. (2013). Penerapan Model Pembelajaran PDEODE (Predict Discuss Explain Observe Discuss Explain) Untuk Meningkatkan Hasil Belajar Teknologi Informasi dan Komunika. KARMAPATI (Kumpulan Artikel Mahasiswa Pendidikan Teknik Informatika), 2(6): 703-708.

[29] Nurkhaliq, N., Bialangi, N., \& Salimi, Y. K. (2018). Pengaruh Model Pembelajaran POE (PredictObserve-Explain) terhadap Kemampuan Pemahaman Konsep Larutan Penyangga Siswa SMA Negeri 1 Gorontalo. Jambura Journal of Educational Chemistry, 13(2): 165-169. 